any hypothesis extant. For example : there t are several flowers which (like several species of insects) are perfected without re. ference to the light or warmth of the sun, and only at certain hours of the day. Linnæus, in his " Philosophia Botanica," divides the day-blooming flowers into three classes, the meteoric, tropical, and equinoctial. Those of the first class are influenced as to their blooming by the state of the weather; of the second by the length of the day; but those of the third open and shut at a fixed and absolutely cerlain hour. From the habits of these last Linnæus formed his Horologium Flore. If a mesembryanthemum be placed in a window facing the east, so that it shall have the morning sun full upon it until twelve o'clock, it will, nevertheless, remain closed until two o'clock, when it will open, although the sun's rays are off it. The observations of Reaumur on certain ephemeræ (quoted in my last communication) are quile analogous; neither cold nor rain re. tarded their exclusion from the pupa during the hours at which they exclusively broke forth, namely, from eight to ten o'clock, p.m. We can only explain those facts on the suppositions, either that plants and insects are governed by habit like ourselves, or that there is some external influence guiding their movements, of which we are quite ignorant. Both, indeed, may be in operation. All phenomena of this vature are exceedingly worthy of the attention of the philosophic naturalist, and present an absolutely novel ficld of research.

Having thus noticed the exoteric influences recurring at the lesser periods, I shall next review those recurring at the greater, and examine the question of lunar influence.

York, Feb. 27, 1843.

\section{WHAT ACTS ARE ESSENTIAL TO CONSTITUTE RAPE?}

\section{To the Editor of THE LaNCET.}

SIR,-I was lately requested by a respectable medical practitioner to examine the person of a child, of fourteen years of age, upon whom it had been stated that a rape had been committed by her own father. My examination was made on the fourth day after the supposed occurrence, and observing no appearauce of bruise about the vulva or parts adjacent, and also distinctly perceiving an unruptured hymen, which I carefully raised on a probe, to be fully satisfied, I ventured to pronounce a positive opinion that no penetration had been perpetrated; and in this $I$ could not be mistaken, as the parts of the child were remarkably small for the age, and could not by possibility have admitted an ordinary-sized male organ, in a state of erection, without most extensive laceration of the hymen. On the trial, which took place at the Old Bailey last Thursday week, two highly respectable medical witnesses stated their belief that the crime of which the prisoner was accused had been perpetrated. I have no exception to offer to the opinion which these gentlemen had formed, because $I$ know them both to be men of integrity, as well as of experience, and I have no doubt that the two apparently opposite opinions can be reconciled; but $I$ wish to direct your attention to the, at present, imperfect legal definition of "rape." Putting aside, entirely, the question as to the emission of the seminal fluid of the male, the point is this:-In what does the crime consist? And if it be answered, "In the penctration by the male organ," then the question arises, In what does penetration consist? And in the reply to this arises the difficulty. If penetration implies merely the introduction of the male organ as far as the vulva, and does not demand for ita com. pletion the introduction of the organ into the vagina, then I am free to admit that in the case under consideration the offence was fully proved; but if the latter condition be requisite, then I positively deny-this not having been accomplished-the commission of the offence. I should much like to know the precise legal definition of rape, according to the most recent Acts of Parliament. Any medical practitioner may be called upon for his evidence in these most unpleasant cases ; and, although we, as medical men, are only bound to answer questions put to us by judge and counsel, and are not required to know much about the legal points of the case, it does appear, from the obscurity of the questions presented to us, that a knowledge of the strict letter of the law may enable us to render assistance, even to the learned judges themselves. Now, if it be required to prove the fact of vaginal pene. tration, as I suspect from the questions put to me by the counsel for the prosecution, and the judge in the case, I think the law is undoubtedly faulty, as it is well known that very many instances are on record of im. pregnation having taken place, the hymen remaining entire; and an innocent female may be subjected to the inconvenience result ing therefrom, without the ability to obtain redress by prosecution; or, at the utmost the charge of assault alone could be main tained against the offending party.

The subject is attended with difficulty, bu as medical testimony, whether positive o negative, does not rank very high in the opi nions of some persons, $I$ have thought it $m$ ! duty to request to be enlightened upon th subject. 1 am, Sir, your obedient servant

London Hospital, March, 1813. JoHn Adans.

Phosphoros may be preserved from th action of the air by a little of the vapour $c$ the oil of turpentine, ether, \&c.-Professo Graham. 